\title{
IMMUNOLOGICAL ASPECTS OF COVID-19: WHAT WE KNOW SO FAR
}

\author{
KAZI ZULFIQUER MAMUN, NABEELA MAHBOOB, KAZI TAIB MAMUN, HASINA IQBAL, AFRIN S
}

\begin{abstract}
The newly emerged severe acute respiratory syndrome coronavirus 2 (SARS-CoV-2) and the disease that it causes coronavirus disease 2019 (COVID19) have changed the world. Many virulence factors and immune mechanisms contribute to the deteriorating effects during SARS-CoV-2 infection. Both humoral and cellular immune responses are involved in the pathophysiology of the disease. The clinical picture of COVID-19, immune memory and reinfection remains unclear and unpredictable. An electronic search of PubMed, Cochrane Library and Google scholar was performed, and citation relevance was determined according to the aim of the review. Other relevant literature was manually searched as compliment. More than 60 relevant scientific articles and reports were considered. We have reviewed the literature describing immunological aspects of COVID-19.Through this review, we tried to explain theimmune pathogenesis of SARS CoV 2infection providing high-quality evidence to understand SARS-CoV-2 pathophysiology, its interaction with target cells and the immune response to the virus, including the contribution of dysfunctional immune responses to disease progression in patients with COVID-19, based on the recent research progress of SARS COV 2 and the knowledge from researches on SARS CoV and MERS CoV. Different therapeutic options have been implemented to find effective, even though not specific, treatment to the disease, many hopes are put in developing an effective vaccine against the virus. Understanding the immunopathogenesis of COVID-19 may provide important clues for effective vaccine and treatments of this disease.
\end{abstract}

Keywords: SARS-CoV-2, COVID-19, Immunopathogenesis

Received: 25 November, 2020

Accepted: 25 December, 2020

DOI: https://doi.org/10.3329/bjm.v32i1.51094

\section{Introduction}

The coronavirus disease 2019 (COVID-19) pandemic, caused by severe acute respiratory syndrome coronavirus 2 (SARS-CoV-2) has affected millions of people worldwide. ${ }^{1}$ The first cases of COVID-19 likely occurred from a zoonotic transmission in China in December 2019. The causative virus is capable of human-to-human transmission and spread rapidly to other parts of China and then other countries. ${ }^{2}$ By 24 March 2020, SARS-CoV-2 had infected more than 381,000 people and killed more than 16,000across 195 countries/regions. A pandemic was declared by the World Health Organization. ${ }^{3}$ Daily reports of sharp rises in the number of new cases continued to emerge from manycountries/regions, but efforts to overcome the virus are hampered by a lack of knowledge of several important aspects of SARS-CoV-2 infection.Alongside investigations into the virology of SARS-CoV-2, understanding the fundamental physiological and immunological processes underlying the clinical manifestations of COVID-19 is vital for the identification and rational design of effective therapies. ${ }^{2}$ In this Review, we summarize the current state of knowledge of the interaction of SARS-CoV-2 with the immune system elicited by SARS-CoV-2 and the immunological pathways that likely contribute to disease progression.

1. MTropMed (UK), PhD (UK), Professor, Department of Microbiology, Popular Medical College, Dhaka.

2. Assistant Professor, Department of Microbiology, Popular Medical College, Dhaka.

3. Research Investigator, icddrb.

4. Associate Professor, Department of Microbiology, Popular Medical College, Dhaka.

5. Lecturer, Department of Microbiology, Popular Medical College, Dhaka.

Corresponding Author: Dr. Nabeela Mahboob, MD (Virology), MPH (Epidemiology), Assistant Professor, Department of Microbiology, Popular Medical College, Dhaka. Email: nabeela.islam311@gmail.com, Contact no.: 01769050442 
PubMed, Cochrane Library and Google Scholar were searched on December 7, 2020, to extract published articles that reported the immunopathology of COVID19 patients. Relevance was judged according to articles describing theories of immune mechanisms influencing the Covid 19 pandemic. We carried out in depth literature review, scrutinizing every article out of total results following a search by key words. About 63 relevant scientific articles and reports were considered from these various databases.

\section{Pathogenesis of COVID-19}

The precise mechanism of COVID-19 pathogenesis remain elusive. However, recent studies in COVID-19 patients and previous studies on Severe acute respiratory syndrome-related coronavirus (SARS-CoV) and Middle East respiratory syndrome coronavirus (MERS-CoV) infections have provided some perceptions into pathogenesis of COVID-19.It has been documented thatthe pathophysiology of SARS-CoV-2 infection closely resembles that of SARS-CoV infection, with aggressive inflammatory responses strongly implicated in the resulting damage to the airways. ${ }^{4}$ Therefore, the severity of the disease is not only due to the viral infection but also due the host response. ${ }^{5,6}$ SARS-CoV-2 is acquired by exposure to microdroplets present in the exhalates of infected individuals or by contact with viral particles present in contaminated fomites. Once the virus reaches the bronchioles and alveolar spaces, the main targets are the cells of the bronchial epithelium and the type-II Angiotensin 2 Converting Enzyme (ACE2+) pneumocytes of the alveolar epithelium. ${ }^{7}$

\section{SARS- CoV-2 entry and replication}

The main receptor for SARS-CoV and SARS-CoV-2 on the membrane of the target cells is the Angiotensin 2 Converting Enzyme (ACE2), a metallopeptidase present on the membrane of many cells, including type-I and -II pneumocytes, small intestine enterocytes, kidney proximal tubules cells, the endothelial cells of arteries and veins, and the arterial smooth muscle, among other tissues. ${ }^{8,9}$ The spike (S) protein is expressed on the surface of the corona virus particles, giving the characteristic 'crown' appearance. The S1 subunit of $\mathrm{S}$ protein consists of an amino-terminal domain and a receptor-binding domain (RBD). ${ }^{10} \mathrm{RBD}$ binding to ACE2 triggers endocytosis of the SARS-CoV-2 virion and exposes it to endosomal proteases. ${ }^{11}$ The $\mathrm{S} 2$ subunit consists of a fusion peptide (FP) region and two heptads repeat regions: HR1 and HR2. ${ }^{12}$ Within the endosome, the $\mathrm{S} 1$ subunit is cleaved away, exposing the fusion peptide, which inserts into the host membrane. The S2 region then folds in on itself to bring the HR1 and HR2 regions together. This leads to membrane fusion and releases the viral package into the host cytoplasm.Chen et al. and Wrappet al. reported that SARS-CoV-2 RBD binds to ACE2 with higher affinity than that of SARS-CoV. ${ }^{13,14}$ In addition, Coutardet al. revealed that the SARS-CoV-2 S protein contains a furin-like cleavage site, similar to MERS-CoV and human coronavirus OC43, which is not found in SARSCoV. ${ }^{15}$ These characteristics could contribute to the increased infectivity of SARS-CoV-2 relative to SARSCoV. In another study by Hoffmann et al. reported the role of the cellular serine protease TMPRSS2 to properly process the SARS-CoV-2 spike protein in addition to furinprecleavage, and facilitate host cell entry. ${ }^{16}$ Thereafter, viral RNA serves as a template for the translation of the polyproteins pp $1 \mathrm{a}$ and $\mathrm{pp} 1 \mathrm{~b}$ that are cleaved into 5-16 non-structural proteins (nsp2nsp9), which in turn induce rearrangement of the membranes to form the vesicles where viral replication and transcription complexes are anchored. The virions are assembled in the ER-Golgi and mature virions are subsequently released by the secretory pathway. ${ }^{17}$

\section{Immune response against SARS- CoV-2}

Immune responses against viruses are rather heterogeneous. An efficient intervention of innate immunity, with its cellular and soluble components, is fundamental to combat the early phases of a primary infection by cytopathic viruses. An efficient innate immune response may control the virus and/or allow sufficient time to mount an efficient T-cell response. ${ }^{\mathbf{1 8}}$

\section{i. The innate immune response}

After the corona viruses enter the host cells, they are recognized by Pattern Recognition Receptors (PRR)expressed by epithelial cells and also the local cells of the innate immune response, such as alveolar macrophages. ${ }^{17}$ Upon ligand binding, there is production of Type-I and -III antiviral Interferons and different chemokines. ${ }^{19}$ These chemokines attract more innate response cells (polymorphonuclear leukocytes, monocytes, NK cells, dendritic cells), which also produce chemokines, such as MIG, IP-10, and MCP1. These recruits lymphocytes, which recognizes the viral antigens presented by DCs. ${ }^{20,21}$ There is scant information regarding the innate responses to SARSCoV-2 in asymptomatic patients or in patients with mild symptoms. The reported lymphopenia may be due to a deficiency in NK cells in patients with severe disease. Further phenotypic and functional studies on NK cell subsets should be performed in these patients in comparison with paucisymptomatic or asymptomatic ones. ${ }^{18}$

Several publications highlighted the initial phases of the SARS-CoV-2 infection, compared to other 
coronavirus, and their effects on subsequent immune and inflammatory responses. Chu et al.compared the in vitro infection of human lung explants with SARS$\mathrm{CoV}$ and SARS-CoV-2 and demonstrated that both viruses can equally infect type-I and -II pneumocytes, plus alveolar macrophages, although SARS-CoV2 had a better capacity to replicate in pulmonary tissues. ${ }^{22}$ While SARS-CoV induced the expression of IFN-I, IFN-II, and IFN-III, but SARS-CoV-2 failed to induce any such immune mediators and was also less efficient in inducting other cytokines. SARSCoVinduced the production of 11 cytokines studied, while SARS-CoV-2 induced only five (IL-6, MCP1, CXCL1, CXCL5, and CXCL10/IP10). Blanco-Melo et al.studied the transcriptional response to SARS-CoV2, compared to SAR-CoV, MERS-CoV, respiratory syncytial virus (RSV), parainfluenza virus 3 (HPIV3), and influenza A virus (IAV), forin vitro infection of respiratory cell lines, experimental in vivo infection of ferrets, and post-mortem lung samples of COVID-19 patients. Their results showed that SARS-CoV-2 reduced IFN-I and IFN-III responses and significant induction of multiple proinflammatory chemokines like IL-1B, IL-6, TNF, and IL1RA. These findings were further supported by the increased serum levels of these molecules in COVID-19 patients. ${ }^{23}$ These studies strongly suggest that SARS-CoV-2 differs from other coronaviruses in its capacity to replicate within the pulmonary tissue, and elude from the antiviral effects of IFN-I and IFN-III, activate innate responses, and induce the production of the cytokines required for the recruitment of adaptive immunity cells. Therefore, the release of large number of virions leads to both infection of neighboring target cells and viremia, the latter resulting in systemic infection since ACE2+ cells are widely distributed in many tissues. 8,9

\section{ii. The adaptive immune response}

The transition between innate and adaptive immune responses is critical for the clinical progress of SARSCoV-2 infection. It is at this crucial moment when immune regulatory events, still poorly understood, probably leads to the development of either a protective immune response or an exacerbated inflammatory response. ${ }^{2,24,25}$

Understanding the antigen presentation of SARS-CoV2 has important role in comprehension of COVID-19 pathogenesis. Unfortunately, there is still lack of report about it, and only some information is available from previous researches on SARS-CoV and MERS-CoV. The antigen presentation of SARS-CoV mainly depends on MHC I molecules ${ }^{26}$ recognized by virus-specific cytotoxic T lymphocytes (CTLs), but MHC II also contributes to its presentation.
The protective response is T cell dependent, where CD4 helps B cells, for the production of specific neutralizing antibodies, and cytotoxic CD8 cells capable of eliminating infected cells. It is worth noting that $80 \%$ of the infiltrating cells in COVID-19 are CD8. ${ }^{27}$

Although T and B cells, macrophages, and DCs do not express ACE2, some reports suggest that DC-SIGN may serve as a trans receptor for SARS-CoV on DCs, which even when not infected may transfer the virus to other susceptible cells. ${ }^{17,21,28}$ Vandakari and Wilce reported that CD26, an aminopeptidase involved in $\mathrm{T}$ cell activation, may bind to the S protein of SARS-CoV-2, resulting in a nonproductive $\mathrm{T}$ cell infection. ${ }^{29}$ Wang et al. reported that SARS-CoV-2 infects human T-cell lines via a novel route through CD147 spike protein, present on the surface of $\mathrm{T}$ lymphocytes. ${ }^{30} \mathrm{CD} 147$, a protein of the immunoglobulins superfamily that induces the metalloproteinases of the extracellular matrix, binds to the $\mathrm{S} 1$ domain and facilitates viral entrance into host cells. The significance of nonproductive $\mathrm{T}$ cell infection may be related to the lymphopenia found in patients with SARS, MERS, and COVID 19. ${ }^{31}$ The binding of SARS-CoV-2 S protein to molecules like CD26 and CD147, which participate in $\mathrm{T}$ cell activation, suggests that a non-productive $\mathrm{T}$ cell infection may result in activation-induced cell death (AICD). There is evidence that T cells are functionally exhausted in patients with severe COVID-19. ${ }^{32}$ These data suggested that a breakdown of antiviral immunity may play a role in the pathogenesis and severity in COVID-19. In CD8+ T cells, the frequency of the nonexhausted (PD-1" CTLA-4" TIGIT") subset in the severe group was significantly lower. It was suggested that the virus promotes an initial excessive activation in the beginning of the disease and is followed by subsequent exhaustion of CD8+ T cells. ${ }^{33}$

A dysfunctional response, unable to inhibit viral replication and elimination of the infected cells, may result in an exacerbated inflammatory response leading possibly to a cytokine storm, manifested clinically by severe acute respiratory distress syndrome (ARDS) and systemic consequences, such as disseminated intravascular coagulation. ${ }^{7}$ In a SARS-CoV primate model of infection, Clay et al.showed that the virus replicated in the lungs until Day 10 post-infection; but, surprisingly, lung inflammation was more intense after virus clearance, reaching its peak at Day 14 and remaining so until Day 28. These results suggest that an early phase dependent on virus replication does occur, while a later viral-independent, immune dependent phase seems to be accompanied by an exacerbated inflammatory component. ${ }^{34}$ The viralindependent phase has been explained by the 
inflammatory reaction secondary to ACE2 inhibition or by an autoimmune phenomenon due to the epitope spreading caused by prolonged tissue destruction. ${ }^{20,35}$ It remains to be demonstrated whether a similar twophase course also occurs in COVID-19.

There is also lack of clear information on the production of specific and neutralizing antibodies (NAbs), crucial for the establishment of a protective immunity. Antibodies specific for the so-called receptor-binding domain (RBD) on $\mathrm{S}$ protein are considered the main targets of NAbs, which is a prerequisite for protection against respiratory coronaviruses (rCoVs). Cocktails of antibodies specific for RBD and other regions of the $S$ protein may further improve the effect of NAbs against SARS-CoV-2 and, eventually, its mutant strains. ${ }^{18}$ Multiple evidences support that the humoral response, mainly antibodies against the $\mathrm{S}$ protein, blocks virus attachment to susceptible ACE2+ cells. ${ }^{36-}$ ${ }^{39}$ However, there are still many questions regarding the significance of antibodies against the different viral proteins, and the cross reactivity of antibodies against other highly prevalent alpha- and beta-coronavirus, although it seems that cross reactivity occurs mostly within the beta-coronaviridae, ${ }^{35,40}$ particularly between SARS-CoV and SARS-CoV-2 that share $90 \%$ of the amino acid sequence in $\mathrm{S} 1 .{ }^{41}$ However, it can also happen with other antigens, as demonstrated in the outbreak of HCoV-OC43 in British Columbia (Canada) where cross reactivity of anti-N antibodies with SARS$\mathrm{CoV}$ was found. ${ }^{42}$ In this respect, there is no information regarding whether survivors of the SARS and MERS epidemics became infected with SARS-CoV2 , and if so, the nature of their clinical and immunological behavior. IgM and IgA antibodies can be detected early during the 1 st week of symptom onset, whereas IgG can be detected at around 14 days after the initiation of symptoms; ${ }^{35,40}$ however, given the short time elapsed since the beginning of the COVID-19 pandemic, it is not known how long the protecting levels of these blocking antibodies will remain active. Nevertheless, in a cohort of SARS survivors followed for 6 years, Tang et al. found that anti-SARS-CoV antibodies were undetectable in 21/ 23 patients and that none of them had specific memory $\mathrm{B}$ cells, whereas specific memory T cells were present in $14 / 23(60.9 \%) .{ }^{43}$ The study of the antibodies against different SARS-CoV-2 antigens, in different populations and at various times during the pandemic, would be an important way of understanding the dynamics of transmission and seroprevalence. Furthermore, it is equally important to conduct serial antibody titers measurements in cohorts of COVID-19 survivors in order to determine how long the immune memory remains active and its effect on the possible reemergence of SARS-CoV-2, or other coronavirus outbreaks.

In patients with SARS, some neutralizing antibodies targeting non-RBD regions of the $\mathrm{S}$ protein caused an antibody-dependent enhancement effect on viral infectivity and disease. ${ }^{20} \mathrm{~A}$ very recent study on 26 patients who recovered from COVID-19 revealed that although most developed antibodies specific for $\mathrm{S}$ protein, only in 3 cases they were specific for the RBD domain. ${ }^{44}$ Ho et al. studying the antibody response in SARS, found that patients with more severe clinical courses had earlier and higher antibody responses, and hypothesized that earlier responders may have had, during the acute phase, cross-reacting antibodies with non-SARS coronaviruses. ${ }^{45}$ Jaumeet al. and Yip et al. demonstrated that anti-S antibodies, while inhibiting viral entrance in permissive cells, potentiated the infection by binding to IgG Fc receptor-II positive (FcãRII+) cells, like B cells and macrophages. ${ }^{46,47}$ Thus, IgG anti-S antibodies bound to FcãRII on mononuclear phagocyte membranes enhance viral entrance through canonical viral-receptor pathways, as recently shown for MERS-CoV, ${ }^{48}$ thereby activating these cells and inducing the production of proinflammatory cytokines.

The role of secretory immunoglobulin A (sIgA) in COVID-19 has received little attention, despite the fact that SARS-CoV-2 enters the body through the respiratory mucosa and SIgA is fundamental to the mucosal defenses. Furthermore, several studies into COVID-19 had shown the presence of serum IgA against SARS-CoV-2 ${ }^{49,50}$ and, in preclinical studies with anti-SARS vaccines, administered either sublingually or intranasally, the presence of neutralizing IgA was demonstrated in bronchoalveolar lavages. ${ }^{51-}$ ${ }^{53}$ These findings support the importance of investigating the presence of sIgA in secretions of patients with COVID-19 and defining its possible antiviral neutralizing activity in respiratory tract mucosa. ${ }^{54}$

\section{Cytokine storm in COVID-19}

COVID-19 infection is accompanied by an aggressive inflammatory response with the release of a large amount of pro-inflammatory cytokines in an event known as "cytokine storm." The host immune response to the SARS-CoV-2 virus is hyperactive resulting in an excessive inflammatory reaction. Several studies analyzing cytokine profiles from COVID-19 patients suggested that the cytokine storm correlated directly 
with lung injury, multiorgan failure, and unfavorable prognosis of severe COVID-19. 55-59 The "cytokine storm" results from a sudden acute increase in circulating levels of different pro-inflammatory cytokines including IL-6, IL-1, TNF- á, and interferon. This increase in cytokines results in influx of various immune cells such as macrophages, neutrophils, and $\mathrm{T}$ cells from the circulation into the site of infection with destructive effects on human tissue resulting from destabilization of endothelial cell to cell interactions, damage of vascular barrier, capillary damage, diffuse alveolar damage, multiorgan failure, and ultimately death. Lung injury is one of the consequences of the cytokine storm that can progress into acute lung injury or its more severe form ARDS. ${ }^{60}$ ARDS leading to low oxygen saturation levels is a major cause of mortality in COVID-19. Although the exact mechanism of ARDS in COVID-19 patients is not fully understood, the excessive production of pro-inflammatory cytokines is considered to be one of the major contributing factors. ${ }^{55,61}$ In a study of 41 hospitalized COVID-19 patients, high levels of pro-inflammatory cytokines were observed in severe cases, including IL-2, IL-7, IL-10, granulocyte-colony stimulating factor, IP-10, MCP-1, macrophage inflammatory protein 1 alpha, and TNF-á. ${ }^{55}$ Predictors of fatality in a retrospective, multicenter study of 150 confirmed COVID-19 cases in Wuhan, China, included elevated ferritin and IL-6 suggesting that mortality might be due to virally driven hyperinflammation. ${ }^{56}$ Another study analyzing data from 21 patients in China reported increased levels of IL-10, IL-6, and TNF-á in severe cases compared to moderate cases. ${ }^{57} \mathrm{~A}$ similar study by Gao et al. assessed 43 patients in China and reported that levels of IL-6 were significantly higher in severe cases than in mild cases. ${ }^{58}$ Similarly, Chen et al. studied a total of 29 COVID-19 patients, divided into three groups according to relevant diagnostic criteria, and found that IL- 6 was higher in critical cases than in severe cases and that IL-6 was higher in severe cases than in mild cases. ${ }^{59}$

\section{Possible mechanisms of immune evasion of SARS- CoV-2}

Data on respiratory coronaviruses, including SARSCoV-2, indicated that these pathogens are particularly prone to evade immune detection and dampen human immune responses. ${ }^{62}$ Taking into account that susceptible HLA haplotypes, high viral load, and previously impaired immunity may contribute to the virus escape of immune response, based on the knowledge of other human respiratory coronaviruses, some other not-mutually exclusive mechanisms of immune evasion can be hypothesized for SARS-CoV-2 (Figure-1). ${ }^{18}$

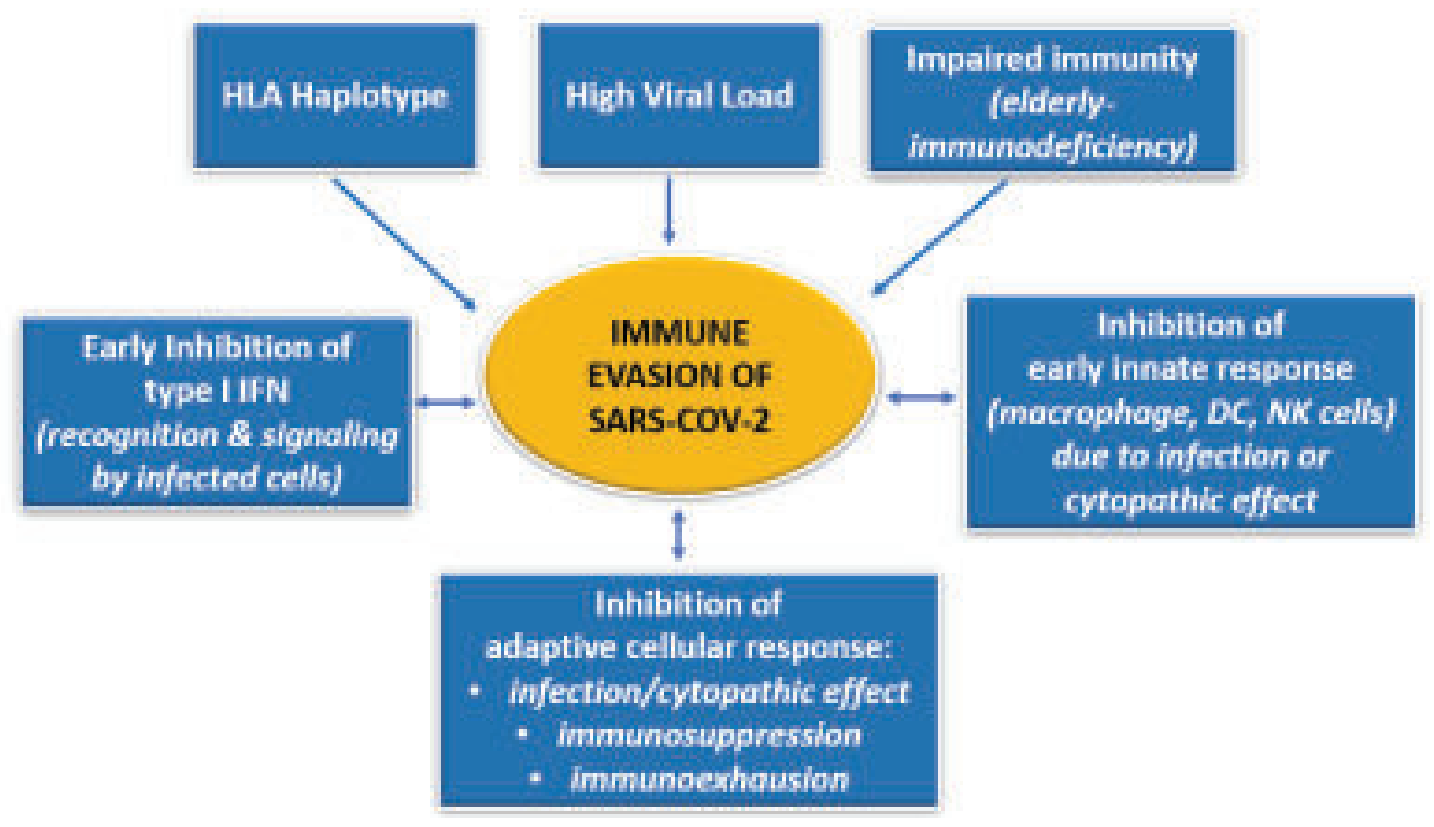

Fig.-1: Possible mechanisms of immune evasion of SARS-CoV-2. ${ }^{18}$ 
Immune evasion of SARS-CoV-2 may be favored in individuals with compromised ability to mount efficient immune responses such as old people and patients with immunodeficiency or individuals carrying HLA alleles unable to properly present SARSCoV-2 peptides to $\mathrm{T}$ lymphocytes. In addition, a high viral load may overcome the barriers of the immune responses. The first mechanism relies on early inhibition of IFN-1 recognition and signaling by infected cells. In rCoVs, IFN-1 is suppressed through different mechanisms directly or indirectly interfering with the signaling of RNA receptors. ${ }^{63}$ Present limitations concern whether and how much the reduced IFN-1 production may compromise the viral control, leading to severe consequences to infected host. Viruses infect cells of both innate and adaptive immunity by exerting a cytopathic effect. In turn, the compromised function of immune cells and the impaired antiviral effect of IFN-1 would further favor immune evasion, resulting in highly detrimental pathological effects.

\section{The clinical-immunological spectrum of covid-19}

In order to understand COVID-19 immunopathogenesis, it is important to elucidate what lies at the root of immune response failure occurring in infected individuals resulting at times in deviation of the protective response into a dysfunctional program, leading to cytokine release syndrome (CRS) with severe inflammation and, eventually, a multi-systemic failure. A better understanding of these events would contribute to the design of differential therapeutic approaches, depending on the stage of the disease, and to the delineation of prognostic, and predictive biomarkers. Unfortunately, there are no studies on the immune response in infected asymptomatic individuals, which would allow a better characterization of the protective immune response as it occurs under the natural conditions of the infection process. ${ }^{7}$ Figure 2 shows diverse outcomes during the course of COVID19 and allows for an analysis of the immune response at each clinical stage. However, it must be noted that the immune response is conditioned by epidemiological variables, such as intensity and duration of exposure to the virus and possible variations in viral virulence and, on the host side, genetic susceptibility/resistance and health conditions at the time of exposure. The latter includes, among other variables, age and the existence of comorbidities that may directly affect the immune system. ${ }^{64}$
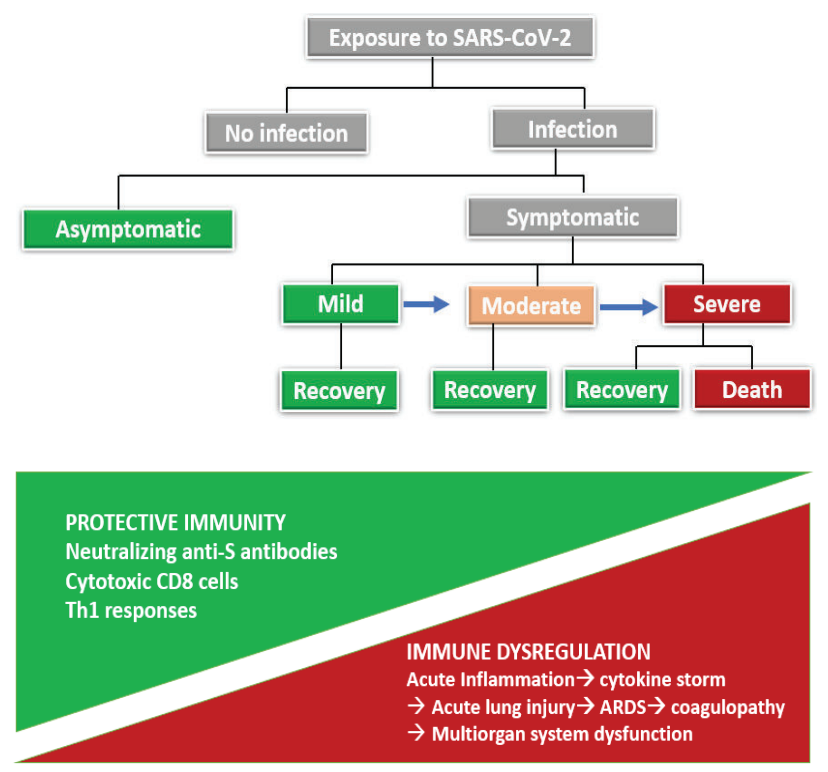

Fig.-2: COVID-19 clinical and immunological spectra 7

Immunological profile in patients with COVID-19 In severe COVID-19 infection, an exacerbated pulmonary and systemic inflammatory response occurs, with increased serum levels of inflammatory markers, such as C-reactive protein (CRP), lactic dehydrogenase (LDH), ferritin, D-dimer, and IL-6, the levels of which are considered predictors of poor outcome. ${ }^{32,55}$

Regarding cellular changes, most studies show that lymphopenia, although present in moderate infections, is more pronounced in severe COVID-19and affects mainly $\mathrm{T}$ cells, including CD4 Th1 and Tregs, but particularly CD8. ${ }^{57,65} \mathrm{Also}$, in severe COVID-19 the number of circulating naive $\mathrm{T}$ cells increases and the number of memory $\mathrm{T}$ cells decreases. ${ }^{66}$ Although the number of CD4 cells decreased, they expressed activation markers such as CD69, CD38, CD44, and HLA-DR, including Th 17 CD4+CCR6+ cells. ${ }^{67} \mathrm{NK}$ cells also decreased in both moderate and severe cases of the disease. ${ }^{68}$ Monocytopeniawas also found in COVID19 patients, particularly in severe cases, but the circulating monocytes belonged mainly to the CD14+CD16+ inflammatory monocyte subset. ${ }^{65}$

Plasma levels of cytokines and chemokines (IL-2, IL2R, IL-6, IL-7, IL-8 IL-10, IP10, MIP1A, and TNFá) 57,66${ }^{68}$ were increased in COVID-19, but were higher in severe infections. High levels of plasmatic IL- 6 had been consistently reported in COVID-19 and even appeared to be associated with poor prognosis and risk of death. ${ }^{64}$ Thus, its measurement has been proposed as a good biomarker to monitor these patients. 


\section{Conclusion:}

This Review has presented the various aspectsof COVID-19 immunopathogenesis. Controlling the inflammatory response may be as important as targeting the virus. The association between immune dysfunction and outcome of disease severity in patients with COVID-19 should serve as a note of caution in vaccine development and evaluation. Further studies of the host immune response to SARS-CoV-2 are necessary, including a detailed investigation of the determinants of healthy versus dysfunctional outcomes.

\section{References:}

1. Florindo HF, Kleiner R, Vaskovich-Koubi D, Acúrcio RC, Carreira B, Yeini E, et al. Immune-mediated approaches against COVID-19. Nat Nanotechnol 2020;15(8):630645. https://doi.org/10.1038/s41565-020-0732-3 PMid:32661375 PMCid:PMC7355525

2. Tay MZ, Poh CM, Rénia L, MacAry PA, Ng LF. The trinity of COVID-19: immunity, inflammation and intervention. Nat Rev Immunol 2020; 1-2. https://doi.org/10.1038/ s41577-020-0311-8 PMid:32346093 PMCid:PMC 7187672

3. World Health Organization. WHO Director-General's opening remarks at the media briefing on COVID-1911 March 2020. WHO. Available from: https:// www.who.int/dg/ speeches/detail/who-directorgeneral-s-openingremarks-at-the-media-briefing-oncovid-19-11- march-2020 (2020). [Retrieved on 10th December, 2020].

4. Wong CK, Lam CW, Wu AK, Ip WK, Lee NL, Chan IH, et al. Plasma inflammatory cytokines and chemokines in severe acute respiratory syndrome. Clin Exp Immunol 2004;136(1):95-103. https://doi.org/10.1111/j.13652249.2004.02415.x PMid: 15030519 PMCid:PMC1808997

5. Huang C, Wang Y, Li X, Ren L, Zhao J, Hu Y, et al. Clinical features of patients infected with 2019 novel coronavirus in Wuhan, China. Lancet 2020;395 (10223):497-506. https://doi.org/10.1016/S01406736(20)30183-5

6. Chen N, Zhou M, Dong X, Qu J, Gong F, Han Y, et al. Epidemiological and clinical characteristics of 99 cases of 2019 novel coronavirus pneumonia in Wuhan, China: a descriptive study. Lancet 2020;395(10223):507-513. https://doi.org/10.1016/S0140-6736(20)30211-7

7. Garcia LF. Immune response, inflammation, and the clinical spectrum of COVID-19. FrontImmunol 2020; 11: 1441. https://doi.org/10.3389/fimmu.2020.01441 PMid:32612615 PMCid:PMC7308593

8. Hamming I, Timens W, Bulthuis LM, Lely TA, Navis G, van GH. Tissue distribution of ACE2 protein, the functional receptor for SARS coronavirus. A first step in understanding SARS pathogenesis. J Pathol 2004;
203:631- 637. https://doi.org/10.1002/path.1570 PMid:15141377 PMCid:PMC7167720

9. Zou X, Chen K, Zou J, Han P, Hao J, Han Z. Single-cell RNA-seq data analysis on the receptor ACE2 expression reveals the potential risk of different human organs vulnerable to 2019-nCoV infection. Front Med 2020; 14:185-192. https://doi.org/10.1007/s11684-0200754-0 PMid:32170560 PMCid:PMC7088738

10. Xiao X, Chakraborti S, Dimitrov AS, Gramatikoff K, Dimitrov DS. The SARS-CoV S glycoprotein: expression and functional characterization. BiochemBiophys Res Commun 2003; 312(4):1159-1164. https://doi.org/ 10.1016/j.bbrc.2003.11.054 PMid:14651994 PMCid: PMC7111010

11. Simmons G, Gosalia DN, Rennekamp AJ, Reeves JD, Diamond SL, Bates P. Inhibitors of cathepsin L prevent severe acute respiratory syndrome coronavirus entry. Proc Natl Acad Sci 2005; 102(33): 11876-11881. https:/ /doi.org/10.1073/pnas.0505577102 PMid:16081529 PMCid:PMC1188015

12. Liu S, Xiao G, Chen Y, He Y, Niu J, Escalante CR, et al. Interaction between heptad repeat 1 and 2 regions in spike protein of SARS-associated coronavirus: implications for virus fusogenic mechanism and identification of fusion inhibitors. Lancet 2004; 363: 938-947. https://doi.org/10.1016/S0140-6736(04) 15788-7

13. Chen Y, Guo Y, Pan Y, Zhao ZJ. Structure analysis of the receptor binding of 2019-nCoV. BiochemBiophys Res Commun 2020; 525, 135-140. https://doi.org/ 10.1016/j.bbrc.2020.02.071 PMid:32081428 PMCid:PMC7092824

14. Wrapp D, Wang N, Corbett KS, Goldsmith JA, Hsieh CL, Abiona O, et al. Cryo-EM structure of the 2019$\mathrm{nCoV}$ spike in the prefusion conformation. Science 2020; 367(6483):1260-1263. https://doi.org/10.1126/ science.abb2507 PMid:32075877 PMCid:PMC7164637

15. Coutard B, Valle C, de Lamballerie X, Canard B, Seidah NG, Decroly E. The spike glycoprotein of the new coronavirus 2019-nCoV contains a furin-like cleavage site absent in CoV of the same clade. Antivir Res 2020; 176:104742. https://doi.org/10.1016/j.antiviral.2020. 104742 PMid:32057769 PMCid:PMC7114094

16. Hoffmann M, Kleine-Weber H, Schroeder S, Krüger N, Herrler T, Erichsen S, et al. SARS-CoV-2 cell entry depends on ACE2 and TMPRSS2 and is blocked by a clinically proven protease inhibitor. Cell 2020; 181(2): 271-280. https://doi.org/10.1016/j.cell.2020.02.052 PMid:32142651 PMCid:PMC7102627

17. Fung TS, Liu DX. Human coronavirus: host-pathogen interaction. AnnRev Microbiol 2019; 73:529-557. https: / /doi.org/10.1146/annurev-micro-020518115759 PMid:31226023

18. Maggi E, Canonica GW, Moretta L. COVID-19: unanswered questions on immune response and 
pathogenesis. JAllergy Clin Immunol2020; 146(1): 1822. https://doi.org/10.1016/j.jaci.2020.05.001 PMid:32389590 PMCid:PMC7205667

19. Hur S. Double-stranded RNA sensors and modulators in innate immunity. Ann Rev Immunol 2019; 37:349375. https://doi.org/10.1146/annurev-immunol042718-041356 PMid:30673536 PMCid:PMC7136661

20. Perlman S, Dandekar AA. Immunopathogenesis of coronavirus infections: implications for SARS. Nat Rev Immunol 2005; 5(12): 917-927. https://doi.org/ 10.1038/nri1732 PMid:16322745 PMCid:PMC7 097326

21. Chen J, Subbarao K. The immunobiology of SARS. Ann Rev Immunol 2007; 25:443-472. https://doi.org/ 10.1146/annurev.immunol.25.022106.141706 PMid:17243893

22. Chu H, Chan FJ, Wang Y, Yuen TT, Chai Y, Hou Y, et al. Comparative replication and immune activation profiles of SARS-CoV-2 and SARS-CoV in human lungs: an ex vivo study with implications for the pathogenesis of COVID-19. Clin Infect Dis 2020. [Epub ahead of print]. https://doi.org/10.1093/cid/ciaa410 PMid:32270184 PMCid:PMC7184390

23. Blanco-Melo D, Nilsson-Payant BE, Liu CW, Uhl S, Hoagland D, Moller R, et al. Imbalanced host response to SARS-CoV-2 drives development of COVID-19. Cell 2020; 181:1036-1045. https://doi.org/10.1016/ j.cell.2020.04.026 PMid:32416070 PMCid:PMC 7227586

24. Manjili RH, Zarei M, Habibi M, Manjili MH. COVID-19 as an acute inflammatory disease. J Immunol 2020; ji 2000413 .https://doi.org/10.4049/ jimmunol.2000413 PMid:32423917

25. FelsensteinS, Herbert AJ, McNamara SP, Hedrich CM. COVID19: Immunology and treatment options. Clin Immunol 2020; 215:108448. https://doi.org/10.1016/ j.clim.2020.108448 PMid:32353634 PMCid:PMC7 185015

26. Liu J, Wu P, Gao F, Qi J, Kawana-Tachikawa A, Xie J, et al. Novel immunodominant peptide presentation strategy: a featured HLA-A 2402-restricted cytotoxic Tlymphocyte epitope stabilized by intrachain hydrogen bonds from severe acute respiratory syndrome coronavirus nucleocapsid protein. J Virol 2010; 84(22):11849-11857. https://doi.org/10.1128/ JVI.01464-10 PMid:20844028 PMCid:PMC2977860

27. Li G, Fan Y, Lai Y, Han T, Li Z, Zhou P, et al. Coronavirus infections and immune responses. J Med Virol 2020; 92:424-432. https://doi.org/10.1002/jmv.25685 PMid:31981224 PMCid:PMC7166547

28. Yang ZY, Huang Y, Ganesh L, Leung K, Kong PW, Schwartz O, et al. pH-dependent entry of severe acute respiratory syndrome coronavirus is mediated by the spike glycoprotein and enhanced by dendritic cell transfer through DC-SIGN. J Virol 2004; 78:5642-5650. https://doi.org/ 10.1128/JVI.78.11.5642-5650.2004 PMid:15140961 PMCid:PMC415834

29. Vankadari N, Wilce JA. Emerging COVID-19 coronavirus: glycan shield and structure prediction of spike glycoprotein and its interaction with human CD26. EmergMicrob Infect 2020; 9:601-604. https:// doi.org/10.1080/22221751.2020.1739565 PMid:32178593 PMCid:PMC7103712

30. Wang K, Chen W, Zhou SY, Lian Q-J, Zhang Z, Du P, et al. SARSCoV-2 invades host cells via a novel route: CD147-spike protein. BioRxiv 2020. [Epub ahead of print]. https://doi.org/10.1101/2020.03.14.988345

31. Wang X, Xu W, Hu G, Xia S, Sun Z, Liu Z, et al. SARSCoV-2 infects $T$ lymphocytes through its spike proteinmediated membrane fusion. Cell Mol Immunol 2020; 7:1-3. https://doi.org/10.1038/s41423-020-0424-9

32. Zheng M, Gao Y, Wang G, Song G, Liu S, Sun D, et al. Functional exhaustion of antiviral lymphocytes in COVID-19 patients. Cell Mol Immunol 2020; 17:533535. https://doi.org/10.1038/s41423-020-0402-2 PMid:32203188 PMCid:PMC7091858

33. Zheng HY, Zhang M, Yang CX, Zhang N, Wang XC, Yang $\mathrm{XP}$, et al. Elevated exhaustion levels and reduced functional diversity of $\mathrm{T}$ cells in peripheral blood may predict severe progression in COVID-19 patients. Cell Mol Immunol 2020;17(5): 541-543. https://doi.org/ 10.1038/s41423-020-0401-3 PMid:32203186 PMCid:PMC709162 1

34. Clay C, Donart N, Fomukong N, Knight BJ, Lei W, Price L, et al. Primary severe acute respiratory syndrome coronavirus infection limits replication but not lung inflammation upon homologous rechallenge. J Virol 2012; 86:4234-44. https://doi.org/10.1128/ JVI.06791-11 PMid:22345460 PMCid:PMC3318632

35. Huang AT, Garcia-Carreras B, Hitchings TDM, Yang B, Katzelnick L, Rattigan MS, et al. A systematic review of antibody mediated immunity to coronaviruses: antibody kinetics, correlates of protection, and association of antibody responses with severity of disease. MedRxiv 2020; 11:4704. [Epub ahead of print]. https://doi.org/ $10.1101 / 2020.04 .14 .20065771$

36. Tai W, He L, Zhang X, Pu J, Voronin D, Jiang S, et al. Characterization of the receptor-binding domain (RBD) of 2019 novel coronavirus: implication for development of RBD protein as a viral attachment inhibitor and vaccine. Cell Mol Immunol 2020; 17:621-630. https:/ / doi org / 10.1038 /s 41423 -020-0400-4 PMid:32203189 PMCid:PMC7091888

37. Ou X, Liu Y, Lei X, Li P, Mi D, Ren L, et al. Characterization of spike glycoprotein of SARS-CoV-2 on virus entry and its immune cross-reactivity with SARS-CoV. Nat Commun 2020; 11:1620. https:// doi.org/10.1038/s41467-020-15562-9 PMid:32221306 PMCid:PMC7100515 
BJM Vol. 32 No. 1

38. He Y, Zhou Y, Liu S, Kou Z, Li W, Farzan M, et al. Receptor-binding domain of SARS-CoV spike protein induces highly potent neutralizing antibodies: implication for developing subunit vaccine. BiochemBiophys Res Commun 2004; 324:773-81. https://doi.org/10.1016/j.bbrc.2004.09.106 PMid:15474494 PMCid:PMC7092904

39. Bonavia A, Zelus DB, Wentworth ED, Talbot JP, Holmes $\mathrm{KV}$. Identification of a receptor-binding domain of the spike glycoprotein of human coronavirus HCoV-229E. J Virol 2003; 77: 2530-2538. https://doi.org/10.1128/ JVI.77.4.2530-2538.2003 PMid:12551991 PMCid:PMC 141070

40. Guo L, Ren L, Yang S, Xiao M, Chang D, Yang F, et al. Profiling early humoral response to diagnose novel coronavirus disease (COVID-19). Clin Infect Dis 2020. [Epub ahead of print].

41. Walls AC, Park JY, Tortorici AM, Wall A, McGuire TA, Veesler D. Structure, function, and antigenicity of the SARS-CoV-2 spike glycoprotein. Cell 2020; 181:28192.e6. https://doi.org/10.1016/j.cell.2020.02.058. PMid:32155444 PMCid:PMC7102599

42. Patrick DM, Petric M, Skowronski MD, Guasparini R, Booth FT, Krajden M, et al. An outbreak of human coronavirus OC43 infection and serological crossreactivity with SARS coronavirus. Canad J Infect Dis Med Microbiol 2006; 17:330-336. https://doi.org/ 10.1155/2006/152612 PMid:18382647 PMCid:PMC 2095096

43. Tang F, Quan Y, Xin ZT, Wrammert J, Ma MJ, Lv H, et al. Lack of peripheral B cell memory responses in recovered patients with Severe Acute Respiratory Syndrome: A six years follow-up study. J Immunol 2011;186: 7264-7268. https://doi.org/10.4049/ jimmunol.0903490 PMid:21576510

44. Chen X, Li R, Pan Z, Qian C, Yang Y, You R, et al. Human monoclonal antibodies block the binding of SARS-CoV2 spike protein to angiotensin converting enzyme 2 receptor. Cell Mol Immunol 2020. [Epub ahead of print]. https://doi.org/10.1038/s41423-020-0426-7 PMid:32313207 PMCid:PMC7167496

45. Ho MS, Chen JW, Chen YH, Lin FS, Wang CM, Di J, et al. Neutralizing antibody response and SARS severity. Emerg Infect Dis 2005; 11:1730-1737. https://doi.org/ 10.3201/eid1111.040659 PMid:16318725 PMCid:PMC 3367364

46. Jaume M, Yip SM, Cheung YC, Leung LH, Li HP, Kien $\mathrm{F}$, et al. Anti-severe acute respiratory syndrome coronavirus spike antibodies trigger infection of human immune cells via a $\mathrm{pH}$ - and cysteine proteaseindependent FcgammaR pathway. J Virol2011; 85:10582-10597. https://doi.org/10.1128/JVI.0067111 PMid:21775467 PMCid:PMC3187504

47. Yip MS, Leung HN, Cheung YC, Li HP, Lee HH, Daeron $M$, et al. Antibody dependent infection of human
Immunological aspects of COVID-19: what we know so far

macrophages by severe acute respiratory syndrome coronavirus. J Virol2014; 11:82. https://doi.org/ 10.1186/1743-422X-11-82 PMid:24885320 PMCid: PMC4018502

48. Wan Y, Shang J, Sun S, Tai W, Chen J, Geng Q, et al. Molecular mechanism for antibody-dependent enhancement of coronavirus entry. J Virol 2020; 94 (5). https://doi.org/10.1128/JVI.02015-19 PMid: 31826992 PMCid:PMC7022351

49. Okba NMA, Muller AM, Li W, Wang C, Geurtsvan Kessel $\mathrm{HC}$, Corman MV, et al. Severe acute respiratory syndrome coronavirus 2-specific antibody responses in coronavirus disease 2019 patients. Emerg Infect Dis 2020; 26 (7): 1478-1488. https://doi.org/10.3201/ eid2607.200841 PMid:32267220 PMCid:PMC7323511

50. Patel R, Babady E, Theel SE, Storch AG, Pinsky AB, St. George K, et al. Report from the American Society for Microbiology COVID-19 International Summit, 23 March 2020: value of diagnostic testing for SARSCoV2/COVID-19. mBio 2020; 11(2):e00722-20. https:// doi.org/10.1128/mBio.00722-20 PMid:32217609 PMCid:PMC7157705

51. Shim BS, Stadler K, Nguyen HH, Yun HC, Kim WD, Chang J, et al. Sublingual immunization with recombinant adenovirus encoding SARS-CoV spike protein induces systemic and mucosal immunity without redirection of the virus to the brain. Virol $\mathrm{J}$ 2012; 9:215-224. https://doi.org/10.1186/1743422X-9-215 PMid:22995185 PMCid:PMC3489719

52. Du L, Zhao G, Lin Y, Sui H, Chan C, Ma S, et al. Intranasal vaccination of recombinant adeno-associated virus encoding receptor-binding domain of severe acute respiratory syndrome coronavirus (SARS-CoV) spike protein induces strong mucosal immune responses and provides long-term protection against SARS-CoV infection. J Immunol 2008, 180:948-956. https:/ / doi.org/10.4049/jimmunol.180.2.948 PMid:18178835 PMCid:PMC2603051

53. Lu B, Huang Y, Huang L, Li B, Zheng Z, Chen Z, et al. Effect of mucosal and systemic immunization with virus-like particles of severe acute respiratory syndrome coronavirus in mice. Immunology 2010; 130: 254-261. https: / / doi.org/10.1111/j.1365-2567.2010.03231.x PMid:20406307 PMCid:PMC2878469

54. Bene MC, de MC, Eveillard M, Lebri Y. Good IgA bad IgG in SARS-CoV-2 infection? Clin Infect Dis 2020. [Epub ahead of print]. https://doi.org/10.1093/cid/ ciaa426 PMid:32280952 PMCid:PMC7184351

55. Huang C, Wang Y, Li X, Ren L, Zhao J, Hu Y, et al. Clinical features of patients infected with 2019 novel coronavirus in Wuhan, China. Lancet 2020; 395:497506. https://doi.org/10.1016/S0140-6736(20)301835

56. Ruan Q, Yang K, Wang W, Jiang L, Song J. Clinical predictors of mortality due to COVID-19 based on an analysis of data of 150 patients from Wuhan, China. 
Intensive Care Med 2020; 46:846-848. https://doi.org/ 10.1007/s00134-020-05991-x https://doi.org/ 10.1007/s00134-020-06028-z PMCid:PMC7131986

57. Chen G, Wu D, Guo W, Cao Y, Huang D, Wang H, et al. Clinical and immunologic features in severe and moderate Coronavirus Disease 2019. J Clin Invest 2020; 130:2620-2629. https://doi.org/10.1172/ JCI137244 PMid:32217835 PMCid:PMC7190990

58. Gao Y, Li T, Han M, Li X, Wu D, Xu Y, et al. Diagnostic utility of clinical laboratory data determinations for patients with the severe COVID-19. J Med Virol 2020; 92:791-796. https://doi.org/10.1002/jmv.25770 PMid:32181911 PMCid:PMC7228247

59. Chen L, Liu H, Liu W, Liu J, Liu K, Shang J, et al. Analysis of clinical features of 29 patients with 2019 novel coronavirus pneumonia. ZhonghuaJie $\mathrm{He} \mathrm{He} \mathrm{Hu}$ Xi Za Zhi 2020; 43:203-208.

60. Shimizu M. Clinical features of cytokine storm syndrome. In: Cron R, Behrens E editors. Cytokine Storm Syndrome. Cham: Springer 2019; 31-42. https:/ /doi.org/10.1007/978-3-030-22094-5_3 PMCid:PMC6371477

61. Lai C, Shih T, Ko W, Tang H, Hsueh P-R. Severe acute respiratory syndrome coronavirus 2 (SARS-CoV-2) and coronavirus disease-2019 (COVID-19): the epidemic and the challenges. Int $\mathrm{J}$ Antimicrob Agents 2020; 55:105924. https://doi.org/10.1016/j.ijantimicag. 2020. 105924 PMid:32081636 PMCid:PMC7127800

62. Kikkert M. Innate immune evasion by human respiratory RNA viruses. J Innate Immun 2020; 12: 420. https://doi.org/10.1159/000503030 PMid:31610541 PMCid:PMC6959104
63. de Wit E, van Doremalen N, Falzarano D, Munster VJ. SARS and MERS: recent insights into emerging coronaviruses. Nat Rev Microbiol 2016; 14: 523-34. https://doi.org/10.1038/nrmicro.2016.81 PMid:27344959 PMCid:PMC7097822

64. Wu C, Chen X, Cai Y, Xia J, Zhou X, Xu S, et al. Risk factors associated with acute respiratory distress syndrome and death in patients with coronavirus disease 2019 pneumonia in Wuhan, China. JAMA Intern Med 2020. [Epub ahead of print]. https:// doi.org/10.1001/jamainternmed.2020.0994 PMid:32167524 PMCid:PMC7070509

65. Zhou Y, Fu B, Zheng X, Wang D, Zhao C, Qi Y, et al. Pathogenic $\mathrm{T}$ cells and inflammatory monocytes incite inflammatory storm in severe COVID-19 patients. Natl Sci Rev 2020. [Epub ahead of print]. https://doi.org/ 10.1093/nsr/nwaa041 PMCid:PMC7108005

66. Qin $\mathrm{C}$, Zhou L, Hu Z, Zhang S, Yang S, Tao Y. Dysregulation of immune response in patients with COVID-19 in Wuhan, China. Clin Infect Dis 2020. [Epub ahead of print]. https://doi.org/10.1093/cid/ciaa248 PMid:32161940 PMCid:PMC7108125

67. Bordoni V, Sacchi A, Cimini E, Notari S, Grassi G, Tartaglia E, et al. An inflammatory profile correlates with decreased frequency of cytotoxic cells in COVID19. Clin Infect Dis 2020. [Epub ahead of print]

68. Wan S, Yi Q, Fan S, Lv J, Zhang X, Guo L, et al. Characteristics of lymphocyte subsets and cytokines in peripheral blood of 123 hospitalized patients with 2019 novel coronavirus pneumonia (NCP). MedRxiv 2020. [Epub ahead of print] https://doi.org/10.1101/ 2020.02.10.20021832 